\title{
Allelic loss at chromosome 11q13 alters FGF3 gene expression in a human breast cancer progression model
}

\author{
DEBASISH ROY ${ }^{1}$ and GLORIA M. CALAF ${ }^{2,3}$ \\ ${ }^{1}$ Department of Natural Sciences, Hostos College of the City University of New York, Bronx, NY, USA; \\ ${ }^{2}$ Instituto de Alta Investigación, Universidad de Tarapacá, Arica, Chile; ${ }^{3}$ Center for Radiological Research, \\ College of Physicians and Surgeons of Columbia University, New York, NY, USA
}

Received July 18, 2014; Accepted August 26, 2014

DOI: $10.3892 /$ or.2014.3502

\begin{abstract}
Identification of markers with the potential to predict tumorigenic behavior is important in breast cancer, due to the variability in clinical disease progression. Genetic alterations during neoplastic progression may appear as changes in total DNA content, single genes, or gene expression. Oncogenic alterations are thought to be prognostic indices for patients with breast cancer. Breast cancer deregulation can occur in the normal cellular process and can be measured by microsatellite instability (MSI)/loss of heterozygosity (LOH). Chromosome 11 is unique in this respect, as three regions of MSI/LOH have been identified (11p15-p15.5, 11q13-q13.3 and 11q23-q24). There are many important families of genes, such as FGF, CCND1, FADD, BAD and GAD2, that are located on chromosome 11 and these play a crucial role in breast cancer progression. Among them, different members of the fibroblast growth factor (FGF) family of genes are clustered around human chromosome 11q13 amplicon, which are constantly altering during breast cancer progression. Therefore, in this study, locus 11q13 and FGF3 gene (11q13) function were investigated in a radiation and estrogen breast cancer model induced by high-LET ( $\alpha$-particle) radiation and estrogen exposure. To assess the effect of ionizing radiation and estrogen at chromosome 11q13 loci and the subsequent role of FGF3 gene expression, various microsatellite markers were chosen in this region, and allelic loses ( 20-45\%) were identified by PCR-SSCP analysis. Results showed an increase in FGF3 protein expression and a 6 - to 8-fold change in gene expression of FGF3 and associated genes. These deregulations could be utilized as an appropriate target for therapeutic intervention in breast cancer.
\end{abstract}

Correspondence to: Dr Debasish Roy, Department of Natural Sciences, Hostos College of the City University of New York, A-507E, 500 Grand Concourse, Bronx, NY 10451, USA

E-mail: droy@hostos.cuny.edu

Key words: microsatellite instability, loss of heterozygosity, high-LET radiation, single strand conformation polymorphism, microarray

\section{Introduction}

Molecular analysis of human and experimental animal cancer models has established that they arise as a result of the deregulation of intricate mechanisms that control cell growth and differentiation. A major theme emerging from such studies is that mutations of both oncogenes and tumor-suppressor genes are required for malignancy, both being necessary for cell transformation and the latter for the expression of the malignant phenotype (1). According to Knudson's 'two hit' hypothesis, many types of human cancers are thought to develop by genetic alterations of putative tumor-suppressor genes that require a biphasic process to eliminate both alleles. Most frequently one of these two events involves the loss of one allele due to chromosomal deletion (2). This allelic alteration may occur either by microsatellite instability (MSI) or loss of heterozygosity (LOH) (3).

It is unclear whether allelic imbalance is the cause or the result of carcinogenesis, but it is probably the most common genetic factor associated with cancer. Identifying markers that have the potential to predict tumorigenic behavior is important in breast cancer due to the variability in clinical disease progression (4). Genetic alterations during neoplastic progression may appear as changes in total DNA content, single genes, or gene expression (5). Oncogenic alterations are thought to be prognostic indices for patients with breast cancer. During the multistage process of mammary carcinogenesis, stepwise accumulation of genetic changes causes uncontrolled growth, disruption of normal glandular architecture, and invasion of epithelial cells into the adjacent stroma, which ultimately leads to the subversion of orderly epithelial tissue organization. This subversion is a hallmark of malignancy and plays a crucial role in tumor progression (6). It also produces frequent allelic losses at various chromosomal regions, such as $1 \mathrm{p}, 3 \mathrm{p}, 6 \mathrm{q}, 8 \mathrm{p}$, $11,13 q, 16 q, 17$ and 18q, associated with breast cancer (7-9).

Chromosome 11 is unique in this context, as at least three separate regions of $\mathrm{LOH} / \mathrm{MSI}$ have been identified (11p15-p15.5, 11q13-q13.3 and 11q23-q24), pointing to a potentially complicated role of this chromosome in breast carcinogenesis $(10,11)$. Cytogenetic studies and microcell-mediated transfer of human chromosome 11 into tumor cell lines have provided additional evidence of the presence of tumor-suppressor genes on chromosome 11 in melanoma, breast cancer and cervical 
cancer $(12,13)$. There are many important families of genes, such as FGF, CCND1, FADD, BAD and GAD2, that are located on chromosome 11 and play a crucial role in breast cancer progression $(14,15)$. Among them, different members of the fibroblast growth factor (FGF) family of genes are clustered around the human chromosome 11q13 amplicon, commonly altered during breast cancer progression (16). Currently, it is well established that activation of various proto-oncogenes, such as c-MYC, c-ERBB-2/NEU and FGF3/INT2, could trigger uncontrolled cell growth and cancer development, but among them FGF3/INT2 gene amplification is found to be a better independent prognostic indicator of human breast cancer (17).

We previously reported chromosomal alterations along 11q23-q24 loci following radiation and estrogen treatment (18) but there is no report available concerning the chromosomal locus 11q13 and alteration of FGF3 gene (11q13) expression. Therefore, to assess the effect of ionizing radiation and estrogen at chromosome 11q13 loci and the subsequent role of FGF3 gene expression, we utilized a human breast cancer model derived from irradiated, transformed and tumorigenic MCF-10F cell lines treated with different doses of high-LET ( $\alpha$-particle) radiation and estrogen exposure (19).

\section{Materials and methods}

Cell lines. The recently established radiation-induced breast carcinogenic model based on the MCF-10F cell line was cultured and used in this study as presently described $(19,20)$. From such a model, the following cell lines were used as control: MCF-10F cell line (passage 40); MCF-10F cell line treated with $17 \beta$-estradiol [estrogen (E); $10^{-8} \mathrm{M}$; Sigma Chemical Co., St. Louis, MO, USA], named Estrogen (19). The experimental cell lines used in this study were as follows: MCF-10F cell line irradiated with a double dose of 60 cGy of $\alpha$ particles, namely $60 \mathrm{cGy} / 60 \mathrm{cGy}$ (Alpha3), which was anchorage-independent but non-tumorigenic in nude mice (19); MCF-10F cell line subjected to a double dose of $60 \mathrm{cGy}$ of $\alpha$ particles and treated with estrogen before each radiation exposure, named $60 \mathrm{cGy}+\mathrm{E} / 60 \mathrm{cGy}+\mathrm{E}$ (Alpha 5), which was anchorage-independent and produced tumors in nude/SCID mouse and after injection gave rise to Tumor2. Phenotypic characteristics of these cell lines and their genetic alterations including differentially expressed genes and expression of various proteins have been previously described (21-24).

DNA isolation. Cell cultures were treated with $1 \mathrm{ml}$ of lysis buffer [100 mM NaCl, $20 \mathrm{mM}$ Tris- $\mathrm{HCl}$ (pH 8.0), $25 \mathrm{mM}$ EDTA (pH 8.0), $0.5 \%$ sodium dodecyl sulfate] with $200 \mathrm{mg} / \mathrm{ml}$ of proteinase $\mathrm{K}$ and RNase $(100 \mu \mathrm{g} / \mathrm{ml})$, and incubated overnight at $37^{\circ} \mathrm{C}$ with constant gentle agitation (25). Then, they were purified and dissolved in TE buffer following standard procedures (26).

Selection of markers for microsatellite polymorphism. Four polymorphic dinucleotide $(\mathrm{CA})_{\mathrm{n}}$ repeat microsatellite markers from chromosome 11q13-q13.3 were selected (Research Genetics, Huntsville, AL, USA). They were selected on the basis of their maximum heterozygosity $(>0.70)$ and their location near mapped, known tumor-suppressor genes, oncogenes or other cancer-related genes (Table IA). The sequences of microsatellite oligonucleotide primers were obtained from the GDB database (http://www.ncbi.nlm.nih.gov/tools/ primer-blast) (Table IB). We also tested D2S123 (2p16, 0.77, dinucleotide, 197-227 bp), a CA repeat marker linked to the HMSH2 gene, mapped at 2p16, where LOH is rarely encountered (data not shown).

PCR-single strand conformation polymorphism analysis. PCR-single strand conformation polymorphism (SSCP) analysis was carried out in a volume of $30 \mu \mathrm{l}$ containing 50-100 ng of genomic DNA, $1.5 \mathrm{mM} \mathrm{MgCl}_{2}, 50 \mathrm{mM} \mathrm{KCl}$, $10 \mathrm{mM}$ Tris- $\mathrm{HCl}$ (pH 8.3), $200 \mu \mathrm{M}$ of each dNTP, $0.8 \mu \mathrm{M}$ of each primer (Research Genetics), and 0.75 units of AmpliTaq polymerase (Perkin-Elmer Corp., Foster City, CA, USA) (27). One of the primers was 5 -end-labeled with $\left[\gamma_{-}{ }^{32} \mathrm{p}\right]$ ATP at $3000 \mathrm{Ci} / \mathrm{mmol}$ (Amersham Pharmacia Biotech., Skokie, IL, USA) by $\mathrm{T}_{4}$-polynucleotide kinase (Amersham Life Science, Arlington Heights, IL, USA). After a 5-min pre-incubation period at $94^{\circ} \mathrm{C}$, DNA was amplified for 35 cycles consisting of $45 \mathrm{sec}$ at $94^{\circ} \mathrm{C}, 45 \mathrm{sec}$ at $55^{\circ} \mathrm{C}$, and $1 \mathrm{~min}$ at $72^{\circ} \mathrm{C}$, followed by a 7-min final extension at $72^{\circ} \mathrm{C}$ using the GeneAmp ${ }^{\circledR} \mathrm{PCR}$ System 2400 (Perkin Elmer/Applied Biosystems, Foster City, CA, USA). PCR products were processed by diluting 1:1 in denaturing loading buffer (95\% formamide, $20 \mathrm{mM}$ EDTA, $0.05 \%$ xylene cyanol $\mathrm{FF}$, and $0.05 \%$ bromophenol blue); denaturing at $95^{\circ} \mathrm{C}$ for $5 \mathrm{~min}$ and then frozen at $4^{\circ} \mathrm{C}$. Two microliters of the aliquot was loaded and electrophoresed on $6 \%$ polyacrylamide gels containing $8.3 \mathrm{M}$ urea for $2-3 \mathrm{~h}$ at $40 \mathrm{~W}$. The gel was fixed in $10 \%$ methanol-10\% acetic acid, dried and exposed to Kodak X-omat-AR film (Eastman Kodak Co., Rochester, NY, USA) at $-70^{\circ} \mathrm{C}$ with an intensifying screen for 12-16 h. PCR reaction was always repeated 2-3 times with different adjacent passages of cells to get consistent results.

Assessment of allelic losses. MSI/LOH were screened by PCR amplification of microsatellite markers. MSI was defined as a shift of a specific allelic band or a change (increase or decrease) in the broadness of a specific allelic band in the autoradiogram, whereas $\mathrm{LOH}$ was defined as a total loss (complete deletion) or a $50 \%$ or more reduction (in signal density) in one of the heterozygous alleles in the autoradiogram. It was first scored by visual inspection of the autoradiogram, and then band intensity was quantified in a densitometric scanner (model 300A) by Image Quant (ver. 3.3; both from Molecular Dynamics). Optical density range of 0.01 to 4.0 was chosen in OD units, whereas spatial resolution was selected at 100 points/cm in both directions ( $\mathrm{x}$ and $\mathrm{y}$ ). Resolution (signal) was selected at 4096 levels (12-bit) of optical density.

Determination of protein expression by immunofluorescence technique. Exponentially growing cells were plated on a glass chamber slide (Nunc Inc., Naperville, IL, USA) as previously described (28), at a density of $1 \times 10^{4}$ cells $/ \mathrm{ml}$ of growth medium. Three independent biological experiments were performed. FGF3 protein expression was detected using the primary antibody (sc-135; in a 1:500 dilution from the original stock concentration; Santa Cruz Biotechnology, Santa Cruz, CA, USA). Rhodamine-conjugated secondary antibody was from Jackson ImmunoResearch Lab., West Grove, PA, USA. 
Table I. Characteristics of selected repeat markers $(\mathrm{CA})_{\mathrm{n}}$ and sequence of sense and antisense primers of microsatellite markers and other important genes located on chromosome 11q13-q13.3.

A, Characteristics of selected repeat markers $(\mathrm{CA})_{\mathrm{n}}$ on chromosome 11q13-q13.3

\begin{tabular}{lcccc}
\hline Chromosomal locus & Map position $^{\mathrm{a}}$ & Maximum heterozygosity & Type of sequence & Size range [base pairs (bp)] \\
\hline D11S2179 & 11q13-q13.3 & 0.792 & Dinucleotide & $123-133$ \\
FGF3 & $11 \mathrm{q} 13$ & 0.853 & Dinucleotide & $198-220$ \\
INT2 & $11 \mathrm{q} 13$ & 0.788 & Dinucleotide & $364-379$ \\
PYGM(CA) & $11 \mathrm{q} 13.1$ & 0.761 & Dinucleotide & $152-160$ \\
\hline
\end{tabular}

B, Sequence of sense and antisense primers of microsatellite markers and other important genes located at chromosome 11q13-q13.3

\begin{tabular}{llr} 
Chromosomal locus & \multicolumn{1}{c}{$\begin{array}{c}\text { Primer sequence } \\
\text { sense }\left(5^{\prime} \rightarrow 3^{\prime}\right) / \text { antisense }\left(5^{\prime} \rightarrow 3^{\prime}\right)\end{array}$} & $\begin{array}{c}\text { Important genes within } \\
\text { these marker regions }\end{array}$ \\
\hline D11S2179 & TAGGCAATACAGCAAGACCCTG/ & bad, Sfg in breast cancer \\
FGF3 & ATTTCCAGAGCCAGCTCAAA/ & ccnd1, fadd, bad, gad2 \\
INT2 & CTTTAATGTTGTGATGACACAAAGC & ccnd1, int2, fgfr \\
PYGM(CA) & AGGAAAGACAAGGTTGTAGG & gad2 in breast cancer, Tsg \\
& CTAGCAGAGTCCACCTACTG/ & \\
\hline
\end{tabular}

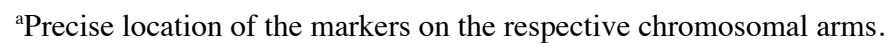

Slides were mounted using Vectashield mounting medium (Vector Laboratories, Burlingame, CA, USA). Cells were examined using Zeiss Axiovert 100 TV microscope (Carl Zeiss, Thornwood, NY, USA) using a 40X 11.3 NA objective lens equipped with a laser scanning confocal attachment (LSM 410; Carl Zeiss, Thornwood, NY, USA). Staining intensity and fluorescent (argon/krypton laser, $488 \mathrm{~nm}$ ) images of the cells were generated and quantified as previously described $(19,24,28)$. A semi-quantitative estimation based on relative staining intensity of protein expression was determined for the parental, non-tumorigenic and tumorigenic cell lines. The number of immunoreactive cells (30 cells/ field) was counted in 5 randomly selected microscopic fields per sample. Standard error of the mean values are shown in the representative figures. Statistical analysis was carried out with the F-test (randomized block) and comparisons between groups with the Bonferroni t-test with $\mathrm{P}<0.05$ considered to indicate a statistically significant difference (29).

Fluorescent-labeled probe preparation for microarray analysis. Poly(A) mRNA from normal, radiation- and estrogen-treated breast cancer cell lines was isolated using QIA-direct mRNA isolation kit (Qiagen). Fluorescent-labeled cDNA was prepared from $1 \mu \mathrm{g}$ of each of these poly(A) mRNAs using oligo dT-primed polymerization and Superscript II reverse transcriptase kit (Life Technologies), in the presence of either Cy3- or Cy5-labeled dCTP following the usual

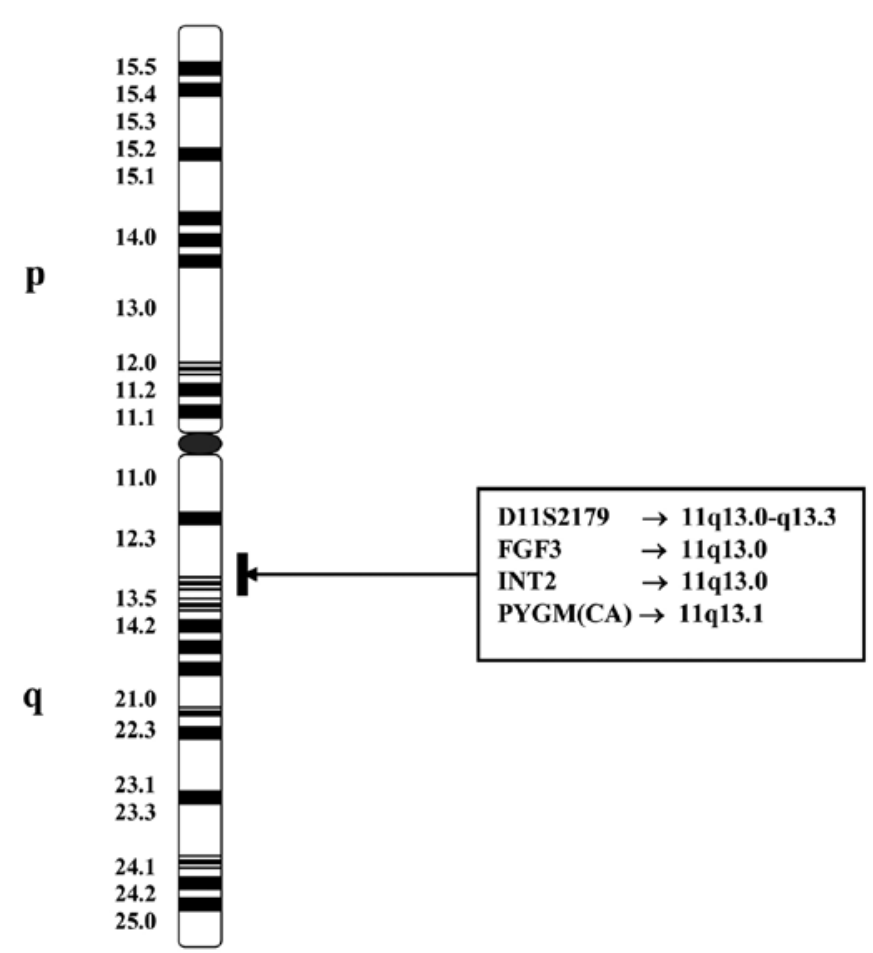

Figure 1. Map of chromosome 11 showing the putative positions of the $(\mathrm{CA})_{\mathrm{n}}$ repeat microsatellite markers used in this study. Bold black vertical lines indicate regions of possible map positions of the markers. 


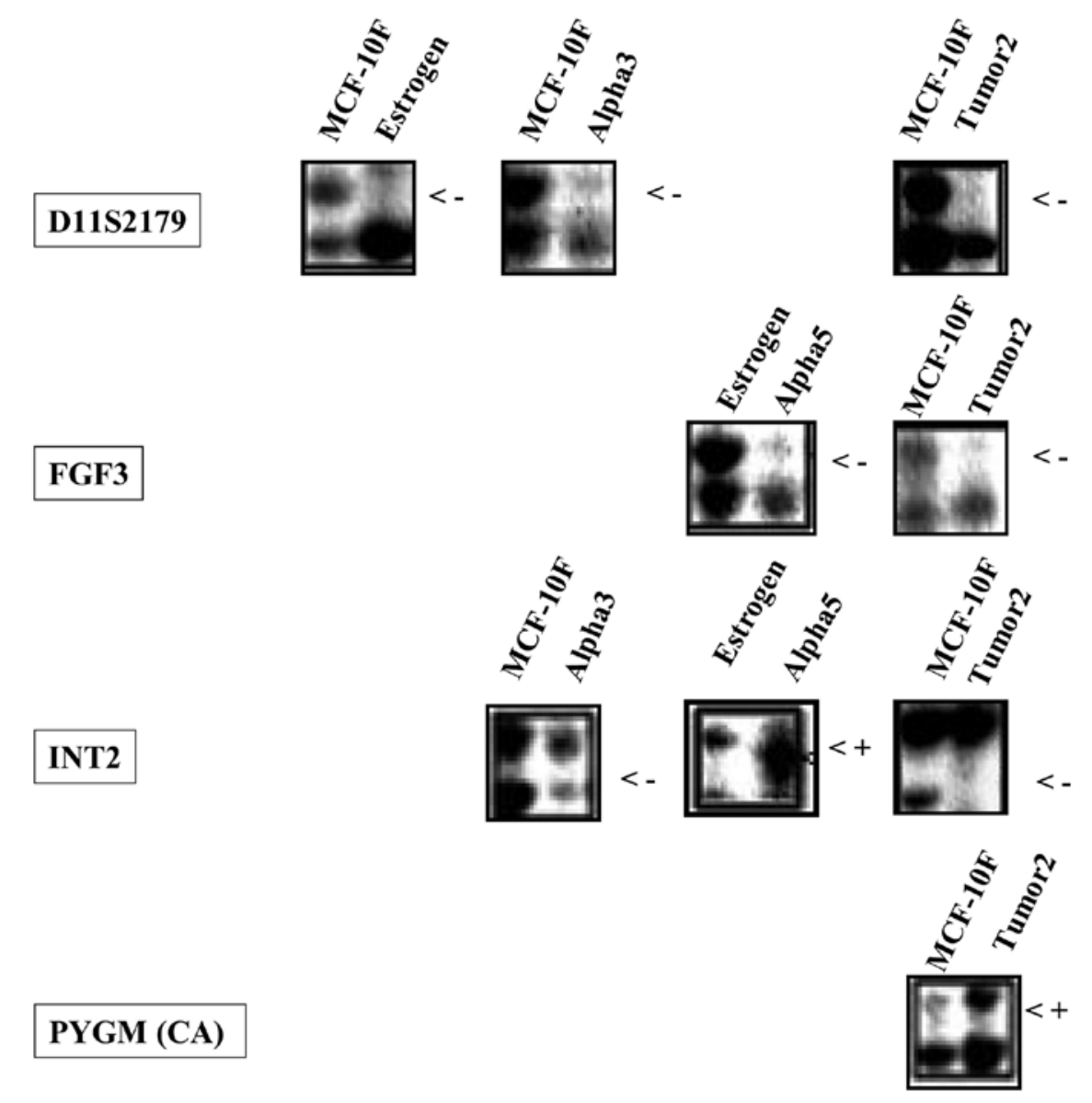

Figure 2. Occurrence of microsatellite instability (<+) and loss of heterozygosity (<-) screened at the respective loci of (CA) $)_{\mathrm{n}}$ repeat markers of chromosome 11q in irradiated, tumorigenic and tumor cell lines.

procedure as described in http://cmgm.stanford.edu/pbrown/ protocols.html. The appropriate Cy3- and Cy5-labeled probes were pooled and hybridized to a microarray in glass coverslips for $16 \mathrm{~h}$ at $65^{\circ} \mathrm{C}$ and then washed with high stringency for analysis.

Analysis of gene expression by Affymetrix HG-U133A Plus 2.0 GeneChip microarray. The breast cancer model (Alpha model) containing the i) MCF-10F, ii) Estrogen iii) Alpha3, iv) Alpha5 and $v$ ) Tumor 2 cell lines was used to analyze gene expression by Affymetrix U133A oligonucleotide microarray (Affymetrix, Santa Clara, CA, USA), which contains 14,500 genes. Arrays were quantitatively analyzed for gene expression using the Affymetrix GeneChip ${ }^{\circledR}$ operating software (GCOS) with dual global scaling option in a Genes@Work software platform of discovery algorithm SPLASH (structural pattern localization analysis by sequential histograms) with a false discovery rate of $0.05(30,31)$.

\section{Results}

A study of allelic losses and altered gene expression in the human breast Alpha model was analyzed in this study. Identification of allelic losses at the specific chromosomal region of 11q13-q13.3 using a total of four microsatellite markers from chromosome 11q13 was used to assess the allelic alterations in an established breast cancer model. Fig. 1 corre- sponds to the map of chromosome 11 showing the putative positions of the $(\mathrm{CA})_{\mathrm{n}}$ repeat microsatellite markers used in this study. Bold black vertical lines indicate regions of possible map positions of the markers. The different degrees of allelic imbalance were expressed in the form of MSI or LOH. This research also focused on the differential gene expression of FGF3 and associated genes at locus 11q13. Table IA documents the characteristics of selected repeat markers $(\mathrm{CA})_{\mathrm{n}}$ on chromosome 11q13-q13.3 and Table IB documents the sequence of sense and antisense primers of the microsatellite markers and other important genes located at chromosome 11q13-q13.3.

Fig. 2 shows the frequency of MSI and LOH at the respective loci of $(\mathrm{CA})_{n}$ repeat markers of chromosome $11 \mathrm{q}$ in irradiated, tumorigenic and tumor cell lines. It was found that alterations were more pronounced in cell lines exposed to double doses of radiation, as well as those in which estrogen was added and in the tumor cell line Tumor 2 compared to control MCF-10F cell lines. These changes were directly correlated with the phenotypic characteristics of the cell lines as they progressed through different stages of transformation to become tumorigenic.

The presence of MSI and $\mathrm{LOH}$ screened at the respective loci of $(\mathrm{CA})_{\mathrm{n}}$ repeat markers of chromosome 11q13-q13.3 in irradiated, tumorigenic and tumor cell lines is shown in Table IIA. The MCF-10F cell line treated with estrogen (Estrogen) was altered in the form of $\mathrm{LOH}$ at locus 11q13.3 (D11S2179) when compared with the control MCF-10F cells. 
Table II. Allelic imbalance and fold change and pair-wise analysis of FGF3 and associated genes in the human breast cancer cell lines.

A, Allelic imbalance in the radiated and estrogen-treated human breast cell lines as detected using different microsatellite markers on chromosome 11q13-q13.3

\begin{tabular}{|c|c|c|c|c|c|c|}
\hline \multirow[b]{2}{*}{ Markers } & \multirow[b]{2}{*}{ Map position } & \multicolumn{5}{|c|}{ Cell lines } \\
\hline & & MCF-10F & Estrogen & Alpha3 & Alpha5 & Tumor2 \\
\hline D11S2179 & $11 q 13-q 13.3$ & $\triangle$ & $\square$ & $\square$ & $\diamond$ & $\square$ \\
\hline FGF3 & $11 q 13$ & $\triangle$ & $\triangle$ & $\triangle$ & $\square$ & $\square$ \\
\hline INT-2 & 11q13 & $\triangle$ & $\triangle$ & $\square$ & O & $\square$ \\
\hline PYGM(CA) & $11 q 13.1$ & $\triangle$ & $\triangle$ & $\triangle$ & $\triangle$ & O \\
\hline
\end{tabular}

B, Fold change and pair-wise analysis of differential expression of FGF3 and associated genes in human breast cell lines identified by Affymetrix HG-U133A Plus 2.0 GeneChip microarray

\begin{tabular}{|c|c|c|c|c|c|c|c|}
\hline \multirow[b]{2}{*}{ Gene } & \multirow[b]{2}{*}{ Genebank } & \multicolumn{6}{|c|}{ Cell lines } \\
\hline & & $\begin{array}{l}\mathrm{MCF} 10 \mathrm{~F} / \\
\text { Estrogen }\end{array}$ & $\begin{array}{l}\text { MCF10F/ } \\
\text { Alpha3 }\end{array}$ & $\begin{array}{l}\text { Estrogen/ } \\
\text { Alpha5 }\end{array}$ & $\begin{array}{l}\text { Alpha3/ } \\
\text { Alpha5 }\end{array}$ & $\begin{array}{l}\text { Alpha5/ } \\
\text { Tumor2 }\end{array}$ & $\begin{array}{l}\text { Alpha3/ } \\
\text { Tumor2 }\end{array}$ \\
\hline $\begin{array}{l}\text { Fibroblast growth } \\
\text { factor binding protein1 }\end{array}$ & NM_005130 & $-1.2(\downarrow)$ & $-21.1(\downarrow)$ & $-9.2(\downarrow)$ & $2.0(\uparrow)$ & $4.2(\uparrow)$ & $8.3(\uparrow)$ \\
\hline $\begin{array}{l}\text { Fibroblast } \\
\text { growth factor } 2 \text { (basic) }\end{array}$ & M27968 & $-1.3(\downarrow)$ & $4.4(\uparrow)$ & $3.0(\uparrow)$ & $-2.0(\downarrow)$ & $-2.8(\downarrow)$ & $-5.5(\downarrow)$ \\
\hline $\begin{array}{l}\text { Fibroblast } \\
\text { growth factor } 2 \text { (basic) }\end{array}$ & NM_002006 & $1.9(\uparrow)$ & $5.8(\uparrow)$ & $3.1(\uparrow)$ & $1.0(\uparrow)$ & $-3.4(\downarrow)$ & $-3.3(\downarrow)$ \\
\hline $\begin{array}{l}\text { Fibroblast } \\
\text { growth factor } 3\end{array}$ & NC_000011.9 & $-1.5(\downarrow)$ & $4.8(\uparrow)$ & $3.6(\uparrow)$ & $-1.8(\downarrow)$ & $-2.3(\downarrow)$ & $-5.8(\downarrow)$ \\
\hline
\end{tabular}

$\triangle$, Retention of heterozygosity; $\square$, loss of heterozygosity $(<-)$; ○, microsatellite instability $(<+)$; $\diamond$, inconclusive. $\uparrow$, upregulation; $\downarrow$, downregulation.

The same locus was also altered in the form of $\mathrm{LOH}$ in the Alpha3 and Tumor2 cell lines with respect to the control MCF-10F. Similarly, the presence of LOH was also identified at locus 11q13 (FGF3) in the Alpha5 and Tumor2 cell lines when compared with the Estrogen and MCF-10F cell lines. The locus 11q13 (INT-2) also showed both LOH and MSI in the different irradiated and tumorigenic cell lines when compared to the control MCF-10F and Estrogen cell lines; Alpha3 and Tumor2 cell lines showed LOH, and MSI was observed in the Alpha5 cell line at this specific locus. Similarly, MSI was noted at locus 11q13.1 [PYGM(CA)] only in the Tumor2 cell line when compared with the MCF-10F cell line.

Fig. 3A shows a histogram representing the average and standard error of FGF3 protein expression in the MCF-10F, Estrogen, Alpha3, Alpha5 and Tumor2 cell lines as determined by immunofluorescence staining by confocal microscopy. Representative images of FGF3 protein expression in the MCF-10F, Estrogen, Alpha3, Alpha5 and Tumor 2 cell lines are shown in Fig. 3B. The results revealed higher protein expression in the Alpha5 and Tumor 2 cell lines when compared with the control MCF-10F cells.
Analysis of gene expression by microarray showed gene expression of FGF3 (11q13) and associated genes such as FGFBP1 and FGF2 in cell lines of the established Alpha model as shown in Table IIB. Fold change and pair-wise analysis of the differential expression of FGF3 and associated genes in the human breast cell lines were identified by microarray. Results of the pair-wise comparison of the cell lines examined for the expression of FGF3 and other associated genes were studied in pairs of cell lines as follows: MCF-10F/Estrogen, MCF-10F/Alpha3, Estrogen/Alpha5, Alpha3/Alpha5, Alpha5/Tumor2 and Alpha3/Tumor2. Results indicated that the pair-wise comparison did not reveal a significant alteration in FGFBP1 gene expression between the MCF-10F/Estrogen and Alpha3/Alpha5 cell lines, whereas an 21-, 9-, 4- and 8 -fold alteration in the MCF-10F/Alpha3, Estrogen/Alpha5, Alpha5/Tumor2 and Alpha3/Tumor2 combinations, respectively, was noted. Similarly, between the MCF-10F/Alpha3 and Alpha3/Tumor 2 combinations an $~ 6$ - and 5-fold change in FGF2 gene expression, respectively, was noted. Finally, combinations of MCF-10F/Alpha3 and Alpha3/Tumor2 cell lines revealed a 5- and 3-fold alteration in FGF3 gene expression, 


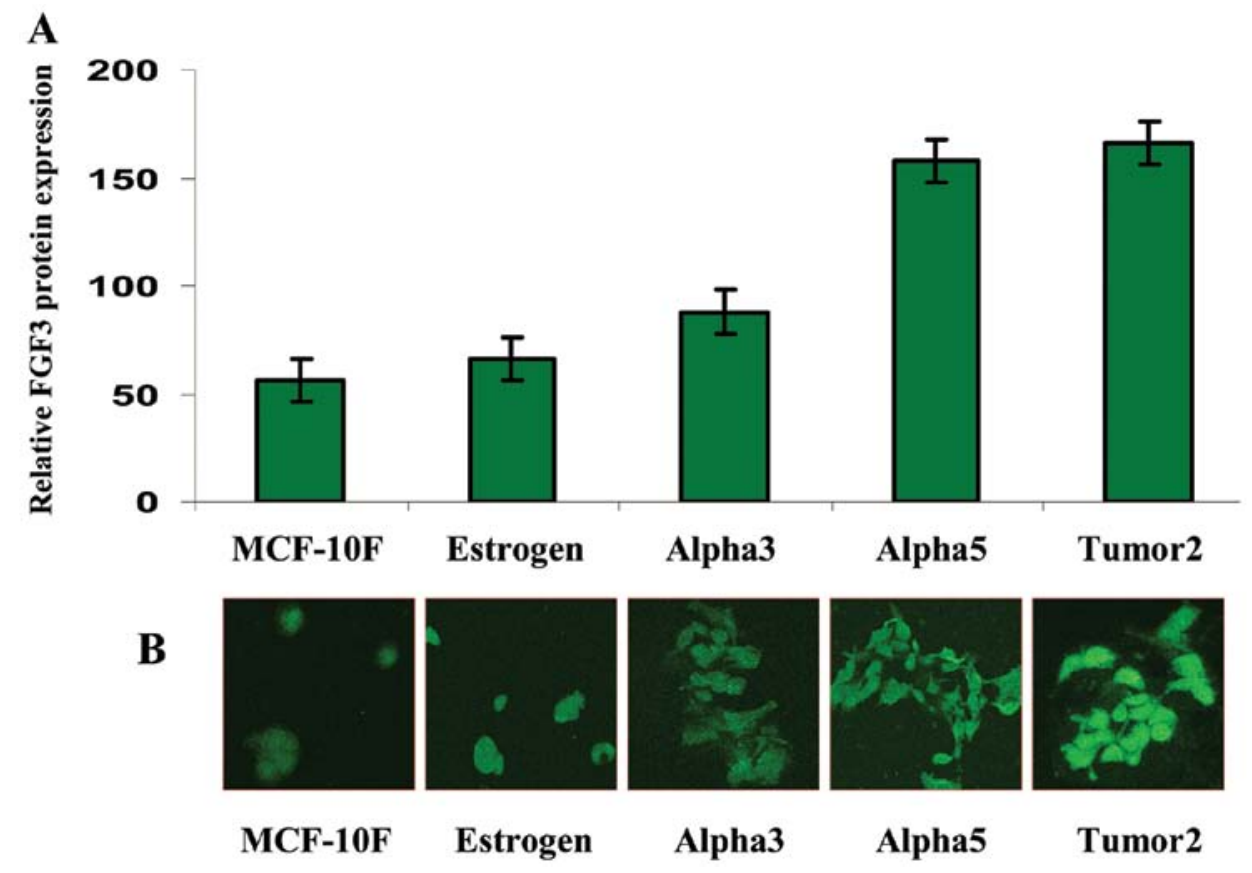

Figure 3. (A) Histogram shows the average and standard error of FGF3 protein expression in the MCF-10F, Estrogen, Alpha3, Alpha5 and Tumor2 cell lines as determined by immunofluorescence staining and quantified using confocal microscopy and a computer program, which provides the area and the intensity of the staining as described in the text. The primary antibody used was a mouse monoclonal antibody. (B) Representative images of FGF3 protein expression in the MCF-10F, Estrogen, Alpha3, Alpha5 and Tumor2 cell lines as determined by immunofluorescence staining.

respectively, whereas there were no significant alterations in the other combinations with respect to this particular gene.

\section{Discussion}

The carcinogenic progression of breast tissues is a complex multi-stage process involving various morphological and genetic alterations including activation of oncogenes and loss or inactivation of tumor-suppressor genes. Thus, tumor cells may have altered genes related to their cell cycle $(19,21)$. An array of genetic anomalies during tumor progression increases the probability of random rearrangements, which favor chromosomal disintegration that leads to $\mathrm{LOH}$, also favoring mitotic recombination, which leads to MSI $(22,32)$.

Our previous study indicated that the combined treatment of ionizing radiation and estrogen yielded different stages in a malignantly transformed breast cancer cell model, which we called the Alpha model system (19). Utilizing this model system, a progressive degree of allelic alterations at 11q13-q13.3 and differential expression of FGF3 and associated genes were detected in the parental, non-tumorigenic and malignantly transformed cell lines originally derived from the parental MCF-10A cell line (20).

Specific microsatellite markers belonging to this particular region were selected on the basis of their role in cell-cycle regulation, DNA replication, DNA repair, or signal transduction of gene proteins $(33,34)$. Therefore, allelic alterations were more pronounced and deleterious when MCF-10F cell lines were exposed to double doses of radiation and treated with estrogen in comparison to the cell lines that were treated with only double doses of radiation without estrogen.

It is now well established that estrogen may play a dual role in affecting breast cancer risk (35). It may serve as a pre-initiator, initiator and promoter of breast cancer by DNA damage and mutations in cells or may reduce breast cancer risk during pregnancy, pre-pubertal period and childhood $(36,37)$. Therefore, these results indicate the importance of estrogen in breast tumor progression. Moreover, studies from other laboratories have already placed various putative tumor-suppressor genes in this larger overlapping area (38-40), which is consistent with our present observation. Again, microcell-mediated chromosome transfer of an intact copy of chromosome 11 into tumorigenic HeLa cells has provided additional support for the presence of a tumor-suppressor gene in this chromosomal region $(11,41)$.

LOH/MSI in this region have been identified in several esophageal and laryngeal squamous cell carcinomas, human renal cell carcinoma, prostate and ovarian cancers as well (42-45). There is also an increasing body of evidence indicating the existence of various driver genes in this region. They show genetic and epigenetic alterations in cancer or cancer-predisposing syndromes (39). 11q13 amplification has also been reported in the local recurrence of human primary breast cancer (46).

Identification of numerous LOH/MSI in the same region (11q13-q13.3 loci) by various independent laboratories has supported the importance of this region in breast cancer. Although, the precise mechanism of the high rate of $\mathrm{LOH} /$ MSI in this particular region is not known, it is evident from different observations that more than one tumor-suppressor gene reside in this region, which also highlights the relevance and usefulness of this model. Their altered imprinting may lead to tumorigenesis by involving a gene activation hypothesis (47).

Notably there are many important families of genes such as FGF, CCND1, FADD, BAD and GAD2 located around 11q13- 
q13.3 with a crucial role in breast cancer progression $(14,15)$. Yet, among them, different members of the FGF family of genes are most important as their amplification is found to be a better independent prognostic indicator of human breast cancer $(17,48)$. In addition, INT-2/FGF3 gene amplications were found to be good indicators of prognosis, potentially in premenopausal patients, and also in lymph node-positive and steroid receptor-negative patients (17). Int-2/FGF3 amplification and progesterone receptor status together proved to be the only independent variable predictive of metastasis-free survival (17). Again, progression in MCF-7 breast cancer cell tumorigenicity also showed the amplification of FGF3 and FGF-4 genes (49). Along with amplification of the FGF family of genes, the fibroblast growth factor receptor (FGFR) cascade also plays crucial roles in tumor cell proliferation, angiogenesis, migration and survival. Accumulating evidence suggests that in some tumor types, FGFRs are bona fide oncogenes to which cancer cells are addicted. Since FGFR inhibition can reduce proliferation and induce cell death in a variety of in vitro and in vivo tumor models harboring FGFR aberrations, a growing number of research groups have selected FGFRs as targets for anticancer drug development (50).

In can be concluded that characterization of this specific locus and alteration of the FGF3 family of genes at this locus is important. Moreover, evaluation of this gene(s) could be used as an additional parameter to identify appropriate target(s) for therapeutic intervention that contribute to radiation-induced breast carcinogenesis. This has broad implications in diagnosing the clinical and pathological aspects of breast cancer, a heterogeneous disease.

\section{Acknowledgements}

The support provided by FONDECYT no. 1120006 (G.M.C.) and MINEDUC-Universidad de Tarapacá (G.M.C.) is greatly appreciated. We also thank Dr Manikandan Jayapal and Dr Praksah Hande of the National University of Singapore for analysis of the Affymetrix microarray data. We are sincerely grateful for the technical assistance of Ricardo Ponce Cusi.

\section{References}

1. Levine AJ: The tumor suppressor genes. Annu Rev Biochem 62: 623-651, 1993.

2. Knudson AG Jr: Genetics and etiology of human cancer. Adv Hum Genet 8: 1-66, 1977.

3. Knudson AG Jr: Mutation and cancer: statistical study of retinoblastoma. Proc Natl Acad Sci USA 68: 820-823, 1971.

4. Wolman SR, Pauley RJ, Mohamad AN, Dawson PJ, Visscher DW and Sarkar FH: Genetic markers as prognostic indicators in breast cancer. Cancer 70: 1765-1774, 1992.

5. Mitelman F: Catalogue of Chromosome Aberration in Cancer. 4th edition. Willey-Liss, New York, NY, 1991.

6. Lengauer C, Kinzler KW and Vogelstein B: Genetic instabilities in human cancers. Nature 396: 643-649, 1998.

7. Devilee P, Van den Broek M, Kuipers-Dijkshoorn N, Kolluri R, Khan PM, Pearson PL and Cornelisse CJ: At least four different chromosomal regions are involved in loss of heterozygosity in human breast carcinoma. Genomics 5: 554-560, 1989.

8. Anderson TI, Gaustad A, Ottestad L, Farrants GW, Nesland JM, Tveit KM and Borresen AL: Genetic alterations of the tumor suppressor gene regions $3 p, 11 p, 17 p$, and $17 q$ in human breast carcinomas. Genes Chromosomes Cancer 4: 113-121, 1992.

9. Roy D, Calaf G and Hei TK: Frequent allelic imbalance on chromosome 6 and 17 correlate with radiation-induced neoplastic transformation of human breast epithelial cells Carcinogenesis 22: 1685-1692, 2001.
10. Winqvist R, Mannermaa A, Alavaikko M, Blanco G,Kiviniemi H, Taskinen PJ, Kiviniemi H, Newsham I and Cavenee W: Refinement of regional loss of heterozygosity for $11 \mathrm{p} 15.5$ in human breast tumors. Cancer Res 53: 4486-4488, 1993.

11. Hampton G, Mannermaa A, Winqvist R, Alavaik ko M, Blanco G, Taskinen PJ, Kiviniemi H, Newsham I, Cavenee W and Evans GA: Loss of heterozygosity in sporadic human breast carcinoma: a common region between 11q22 and 11q23.3. Cancer Res 54: 4586-4589, 1994.

12. Negrini M, Sabbioni S, Possati L, Rattan S, Corallini A, Barbanti-Brodano $G$ and Croce CM: Suppression of tumorigenecity of breast cancer cells by microcell-mediated chromosome transfer: studies on chromosome 6 and 11. Cancer Res 54: 1331-1336, 1994.

13. Rosa-Rosa JM, Pita G, González-Neira A, Milne RL, Fernandez V, Ruivenkamp C, van Asperen CJ, Devilee P and Benitez J: A $7 \mathrm{Mb}$ region within 11q13 may contain a high penetrance gene for breast cancer. Breast Cancer Res Treat 118: 151-159, 2009.

14. Karlsson E, Waltersson MA, Bostner J, Pérez-Tenorio G, Olsson B, Hallbeck AL and Stäl O: High-resolution genomic analysis of the 11q13 amplicon in breast cancers identifies synergy with $8 \mathrm{p} 12$ amplification, involving the mTOR targets S6K 2 and 4EBP1. Genes Chromosomes Cancer 50: 775-787, 2011.

15. Lizard-Nacol S, Lidereau R, Collin FA, Arnal M, Hahnel L, Roignot P, Cuisenier, J and Guerrin J: Benign breast disease: absence of genetic alterations at several loci implicated in breast cancer malignancy. Cancer Res 55: 4416-4419, 1995.

16. Fantl V, Smith R, Brookes S, Dickson C and Peters G: Chromosome 11q13 abnormalities in human breast cancer. Cancer Surv 18: 77-94, 1993.

17. Champème MH, Bièche I, Hacène $K$ and Lidereau R: Int-2/FGF3 amplification is a better independent predictor of relapse than c-myc and c-erbB-2/neu amplifications in primary human breast cancer. Mod Pathol 7: 900-905, 1994.

18. Roy D, Calaf GM, Hande MP and Hei TK: Allelic imbalance at 11q23-q24 chromosome associated with estrogen and radiationinduced breast cancer progression. Int J Oncol 28: 667-674, 2006

19. Calaf GM and Hei TK: Establishment of a radiation- and estrogeninduced breast cancer model. Carcinogenesis 21: 769-776, 2000.

20. Soule H, Vazquez J, Long A, Albert S and Brennan MA: A human cell line from a pleural effusion derived from a breast carcinoma. J Natl Cancer Inst 51: 1409-1416, 1973.

21. Roy D, Calaf GM and Hei TK: Profiling of differentially expressed genes induced by high linear energy transfer radiation in breast epithelial cells. Mol Carcinogen 31: 192-203, 2001.

22. Roy D, Calaf G and Hei TK: Allelic imbalance at 11p15.5-15.4 correlated with c-Ha-ras mutation during radiation-induced neoplastic transformation of human breast epithelial cells. Int J Cancer 103: 730-737, 2003.

23. Calaf GM, Roy D and Hei TK: Immunochemical analysis of protein expression in breast epithelial cells transformed by estrogens and high linear energy transfer (LET) radiation. Histochem Cell Biol 124: 261-274, 2005.

24. Calaf G and Hei TK: Oncoprotein expression in human breast epithelial cells transformed by high-LET radiation. Int J Radiat Biol 77: 31-40, 2001.

25. Gross-Bellard $M$, Oudet $P$ and Chambon $P$ : Isolation of high-molecular-weight DNA from mammalian cells. Eur J Biochem 36: 32-38, 1973.

26. Sambrook J, Fritsch EF and Maniatis T (eds): Molecular Cloning. A Laboratory Manual. Vol 3, 2nd edition. Cold Spring Harbor Laboratory Press, Plainview, NY, pp1626, 1989.

27. Jaeckel S, Epplen JT, Kauth M, Miterski B, Tschentscher F and Epplen C: Polymerase chain reaction-single strand conformation polymorphism or how to detect reliably and efficiently each sequence variation in many samples and many genes. Electrophoresis 19: 3055-3061, 1998.

28. Calaf GM and Roy D: Gene and protein expressions induced by 17 beta-estradiol and parathion in cultured breast epithelial cells. Mol Med 13: 255-265, 2007.

29. Calaf GM and Roy D: Cell adhesion proteins altered by $17 \beta$ estradiol and parathion in breast epithelial cells. Oncol Rep 19: $165-169,2008$.

30. Califano A: SPLASH: structural pattern localization analysis by sequential histograms. Bioinformatics 16: 341-357, 2000.

31. Calaf GM, Roy D, Narayan G and Balajee AS: Differential expression of cell adhesion molecules in an ionizing radiationinduced breast cancer model system. Oncol Rep 30: 285-291, 2013.

32. Bieche I and Lidereau R: Genetic alterations in breast cancer. Genes Chromosomes Cancer 14: 227-251, 1995. 
33. Parsons R, Li GM, Longley MJ, Fang WH, Papadopoulos $\mathrm{N}$, Jen J, De la Chapelle A, Kinzler KW, Vogelstein B and Modrich P. Hypermutability and mismatch repair deficiency in $\mathrm{RER}^{+}$tumor cells. Cell 75: 1227-1236, 1993.

34. Dedhar S: Cell-substrate interactions and signaling through ILK. Curr Opin Cell Biol 12: 250-256, 2000.

35. Hilakivi-Clarke L: Estrogens, BRCA1, and breast cancer. Cancer Res 60: 4993-5001, 2000.

36. Liehr JG: Is estradiol a genotoxic mutagenic carcinogen? Endocr Rev 21: 40-54, 2000.

37. Berkey CS, Frazier AL, Gardner JD and Colditz GA: Adolescence and breast carcinoma risk. Cancer 85: 2400-2409, 1999.

38. Nagahata T, Hirano A, Utada Y, Tsuchiya S, Takahashi K, Tada T, Makita M, Kasumi F, Akiyama F, Sakamoto G, Nakamura Y and Emi M: Correlation of allelic losses and clinicopathological factors in 504 primary breast cancers. Breast Cancer 9: 208-215, 2002.

39. Wilkerson PM and Reis-Filho JS: The 11q13-q14 amplicon: clinicopathological correlations and potential drivers. Genes Chromosomes Cancer 52: 333-355, 2013.

40. Holm K, Staaf J, Jönsson G, Vallon-Christersson J, Gunnarsson H, Arason A, Magnusson L, Barkardottir RB, Hegardt C, Ringnér M, and Borg A: Characterization of amplification patterns and target genes at chromosome 11q13 in CCND1-amplified sporadic and familial breast tumors. Breast Cancer Res Treat 133: 583-594, 2012.

41. Saxon PJ, Srivatsan ES and Stanbridge EJ: Introduction of human chromosome 11 via microcell transfer controls tumorigenic expression of HeLa cells. EMBO J 5: 3461-3466, 1986.

42. Shi ZZ, Jiang YY, Hao JJ, Zhang Y, Zhang TT, Shang L, Liu SG, Shi $\mathrm{F}$ and Wang MR: Identification of putative target genes for amplification within 11q13.2 and 3q27.1 in esophageal squamous cell carcinoma. Clin Transl Oncol 8: 606-615, 2013.
43. Jarmuz-Szymczak M, Pelinska K, Kostrzewska-Poczekaj M, Bembnista E, Giefing M, Brauze D, Szaumkessel M, Marszalek A, Janiszewska J, Kiwerska K, Bartochowska A, Grenman R, Szyfter W and Szyfter K: Heterogeneity of 11q13 region rearrangements in laryngeal squamous cell carcinoma analyzed by microarray platforms and fluorescence in situ hybridization. Mol Biol Rep 40: 4161-4171, 2013.

44. Su T, Han Y, Yu Y, Tan X, Li X, Hou J, Du Y, Shen J, Wang G, Ma L, Jiang S, Zhang H and Cao G: A GWAS-identified susceptibility locus on chromosome 11q13.3 and its putative molecular target for prediction of postoperative prognosis of human renal cell carcinoma. Oncol Lett 6: 421-426, 2013.

45. Chung CC, Boland J, Yeager M, Jacobs KB, Zhang X, Deng Z, Matthews C, Berndt SI and Chanock SJ: Comprehensive resequence analysis of a 123-kb region of chromosome 11q13 associated with prostate cancer. Prostate 72: 476-486, 2012.

46. Champème MH, Bièche I, Lizard S and Lidereau R: 11q13 amplification in local recurrence of human primary breast cancer. Genes Chromosomes Cancer 12: 128-133, 1995.

47. Feinberg AP: Genomic imprinting and gene activation in cancer. Nat Genet 4: 110-113, 1993.

48. Naidu R, Wahab NA, Yadav M, Kutty MK and Nair S: Detection of amplified int-2/FGF-3 gene in primary breast carcinomas using differential polymerase chain reaction. Int J Mol Med 8: 193-198, 2001.

49. Hajitou A, Deroanne C, Noël A, Collette J, Nusgens B, Foidart JM and Calberg-Bacq CM: Progression in MCF-7 breast cancer cell tumorigenicity: compared effect of FGF-3 and FGF-4. Breast Cancer Res Treat 60: 15-28, 2000.

50. Dienstmann R, Rodon J, Prat A, Perez-Garcia J, Adamo B, Felip E, Cortes J, Iafrate AJ, Nuciforo P and Tabernero J: Genomic aberrations in the FGFR pathway: opportunities for targeted therapies in solid tumors. Ann Oncol 20: 552-563, 2014. 